Check for updates

Cite this: RSC Adv., 2018, 8, 35753

Received 3rd September 2018 Accepted 7th October 2018

DOI: $10.1039 / c 8 r a 07352 j$

rsc.li/rsc-advances

\section{Fast and safe synthesis of micron germanium in an ammonia atmosphere using $\mathrm{Mo}_{2} \mathrm{~N}$ as catalyst}

\author{
Baojun Ma, D * Dekang Li, Xiaoyan Wang and Keying Lin
}

Here, we reported a new method for fast and safe synthesis of a micron germanium (Ge) semiconductor. The Ge was successfully prepared from mixed $\mathrm{GeO}_{2}$ with a low amount of $\mathrm{MoO}_{3}$ by the $\mathrm{NH}_{3}$ reduction method at $800{ }^{\circ} \mathrm{C}$ for an ultra-short time of $10 \mathrm{~min}$. XRD patterns show that the Ge has a tetragonal structure. SEM images show that the size of the Ge particles is from $5 \mu \mathrm{m}$ to $10 \mu \mathrm{m}$, and so it is on the micron scale. UV-visible diffuse reflectance spectroscopy shows that the Ge has good light absorption both in the ultraviolet and visible regions. The formation of Ge mainly goes through a two-step conversion in the $\mathrm{NH}_{3}$ flow. Firstly, $\mathrm{GeO}_{2}$ is converted to $\mathrm{Ge}_{3} \mathrm{~N}_{4}$, and then $\mathrm{Ge}_{3} \mathrm{~N}_{4}$ is decomposed to generate $\mathrm{Ge}$. The comparison experiments of $\mathrm{MoO}_{3}$ and $\mathrm{Mo}_{2} \mathrm{~N}$ demonstrate that $\mathrm{Mo}_{2} \mathrm{~N}$ is the catalyst for the $\mathrm{Ge}$ synthesis which improves the $\mathrm{Ge}_{3} \mathrm{~N}_{4}$ decomposition. The presented fast and safe synthesis method of $\mathrm{Ge}$ has great potential for industrialization and the proposed $\mathrm{MO}_{2} \mathrm{~N}$ boosting the $\mathrm{Ge}_{3} \mathrm{~N}_{4}$ decomposition has provided significant guidance for other nitride decomposition systems.

\section{Introduction}

With the development of advanced electronic information industries, semiconductor materials have attracted widespread attention due to their unique optical and electrical properties..$^{1-6}$ Ge as an important semiconductor material with stable chemical properties and obvious non-metallic properties has many advantages, such as non-toxicity, biocompatibility, electrochemical stability, current microelectronics compatibility, etc. $^{7-13}$ At present, Ge has extensive and important applications in fields such as semiconductors, aerospace measurement and control, nuclear physics detection, optical fiber communication, infrared optics, solar cells, chemical catalysts, and biomedicine..$^{14-20} \mathrm{Ge}$ is one of the most dispersed elements and there is almost no concentrated Ge deposit in the Earth's crust. Thus, it is particularly important to find suitable methods to enrich, prepare and purify Ge.

The synthetic method of Ge can be divided into physical and chemical methods. The physical methods mainly include chemical vapor deposition, ${ }^{21}$ gas phase pyrolysis, ${ }^{22}$ plasma technology ${ }^{23-25}$ sputtering, ${ }^{26,27}$ etching, ${ }^{28,29}$ laser ablation ${ }^{30}$ and so on. However, these technological processes need extreme temperatures and pressures and are expensive. Chemical methods mainly include room temperature reduction of a GeCl $/ \mathrm{Br}_{4}$ precursor, ${ }^{31,32}$ high temperature reduction of a $\mathrm{GeI}_{2} /$ $\mathrm{I}_{4}$ precursor, ${ }^{33,34}$ a one-step synthesis method, ${ }^{35,36}$ an electrodeposition method ${ }^{37-41}$ and so on. In the industry, rough Ge is

State Key Laboratory of High-efficiency Coal Utilization and Green Chemical Engineering, College of Chemistry and Chemical Engineering, Ningxia University, Yinchuan, 750021, People's Republic of China.E-mail: bjma@nxu.edu.cn commonly prepared by the reduction of $\mathrm{GeO}_{2}$ in hydrogen flow at $650-680{ }^{\circ} \mathrm{C}$, and then Ge with high purity is obtained by chemical gasification and decomposition of rough Ge. However, in the process of preparing rough $\mathrm{Ge}$, the produced hydrogen is a dangerous gas due to its large range of the explosion limit. In addition, a leak of hydrogen is not easy to discover due to it being colorless and tasteless. So, it is necessary to develop and improve a safe and low-cost method to produce rough Ge.

Ammonia is an important chemical raw material, which has important applications in industrial and agricultural production. At the same time, ammonia is also a reducing gas capable of reducing various metal oxides. ${ }^{42-45}$ Here, we successfully prepared micron Ge material in ammonia atmosphere using $\mathrm{GeO}_{2}$ as raw material with some $\mathrm{MoO}_{3}$ in 10 min. The transformation process from $\mathrm{GeO}_{2}$ to $\mathrm{Ge}$ and the molybdenum based catalyst were determined. The synthesis method of Ge has the advantages of safe, fast and low cost, which is beneficial to industrial production.

\section{Experimental}

\subsection{Synthesis of Ge}

All the chemical agents are from China National Pharmaceutical Group Corporation. $\mathrm{GeO}_{2}$ as raw material and a small amount of $\mathrm{MoO}_{3}$ are mixed and milled in a mortar for 30 minutes. The mixed samples are the calcined in an ammonia flow of $100 \mathrm{~mL} \mathrm{~min}^{-1}$ at different temperature and for different time. The synthesis of Ge in $\mathrm{H}_{2}$ flow is same as that in $\mathrm{NH}_{3}$ flow except $\mathrm{H}_{2}$ instead of $\mathrm{NH}_{3}$.

Also, in this paper $\mathrm{A} / \mathrm{B}$ means A mixed with $\mathrm{B}$. For example, $\mathrm{Mo}_{2} \mathrm{~N} / \mathrm{GeO}_{2}$ means $\mathrm{Mo}_{2} \mathrm{~N}$ mixed with $\mathrm{GeO}_{2}$. 


\subsection{Characterization}

The structure of the as-prepared Ge was determined by X-ray diffraction (D/MAX2500, Rigaku, Japan) with a $\mathrm{Cu}-\mathrm{K}_{\alpha}$ radiation at a voltage of $4 \mathrm{kV}$ at room temperature. The ultravioletvisible diffuse reflectance spectra (UV-vis DRS) were obtained on a spectrometer (U-4100), and $\mathrm{BaSO}_{4}$ was used for the corrected base line. The size and morphology were examined by scanning electron microscopy (SEM, JSM7500F) with the accelerating voltage of $0.5-30 \mathrm{kV}$ and transmission electron microscopy (TEM, F20) with the accelerating voltage of $120 \mathrm{kV}$.

\section{Results and discussion}

\subsection{Synthesis of $\mathrm{Ge}$ in $\mathrm{NH}_{3}$ flow using Mo based catalyst}

Fig. 1 shows the XRD patterns of $\mathrm{GeO}_{2}$ calcined at different temperatures in an ammonia atmosphere. The XRD of the $\mathrm{GeO}_{2}$ is also present for comparison. When the reaction temperature is lower than $800{ }^{\circ} \mathrm{C}, \mathrm{GeO}_{2}$ (PDF \# 36-1463) still remain unchanged. At $800{ }^{\circ} \mathrm{C}$, all $\mathrm{GeO}_{2}$ changed into $\mathrm{Ge}_{3} \mathrm{~N}_{4}$ (PDF \# 381374). At $900{ }^{\circ} \mathrm{C}$, a part of $\mathrm{Ge}$ (PDF \# 04-0545, $2 \theta=27.5^{\circ}$ ) generates which indicates a small part of $\mathrm{Ge}_{3} \mathrm{~N}_{4}$ decomposes at overhigh temperature.

Fig. 2 shows the XRD patterns of $5.0 \mathrm{wt} \% \mathrm{MoO}_{3} / \mathrm{GeO}_{2}$ calcined in $\mathrm{NH}_{3}$ flow at different temperatures for $2 \mathrm{~h}$. It can be seen that when the reaction temperature is at or above $800{ }^{\circ} \mathrm{C}$, almost all the $\mathrm{GeO}_{2}$ are changed into Ge (PDF \# 04-0545). Comparing with Fig. 1, the introduction of the Mo element decreases the reaction temperature of Ge generation over $100{ }^{\circ} \mathrm{C}$.

Fig. 3 shows XRD patterns of $5.0 \mathrm{wt} \% \mathrm{MoO}_{3} / \mathrm{GeO}_{2}$ calcined in $\mathrm{NH}_{3}$ flow at $800{ }^{\circ} \mathrm{C}$ for different time. The process of $\mathrm{Ge}$ generation is ultra fast and almost all the $\mathrm{GeO}_{2}$ can be reduced to $\mathrm{Ge}$ in $10 \mathrm{~min}$. Fig. 4 shows the XRD pattern of $\mathrm{MoO}_{3} / \mathrm{GeO}_{2}$ with different mass ratio calcined in ammonia flow. When the amount of $\mathrm{MoO}_{3}$ is less than $5.0 \%$, the reaction product is Ge and $\mathrm{Ge}_{3} \mathrm{~N}_{4}$ (e.g. the sample of $2.0 \mathrm{wt} \% \mathrm{MoO}_{3} / \mathrm{GeO}_{2}$ ). When the amount of $\mathrm{MoO}_{3}$ is $5.0 \%$, almost all the $\mathrm{GeO}_{2}$ is converted to Ge. In view of the fact of that $\mathrm{GeO}_{2}$ changed into $\mathrm{Ge}_{3} \mathrm{~N}_{4}$ (Fig. 1, 800

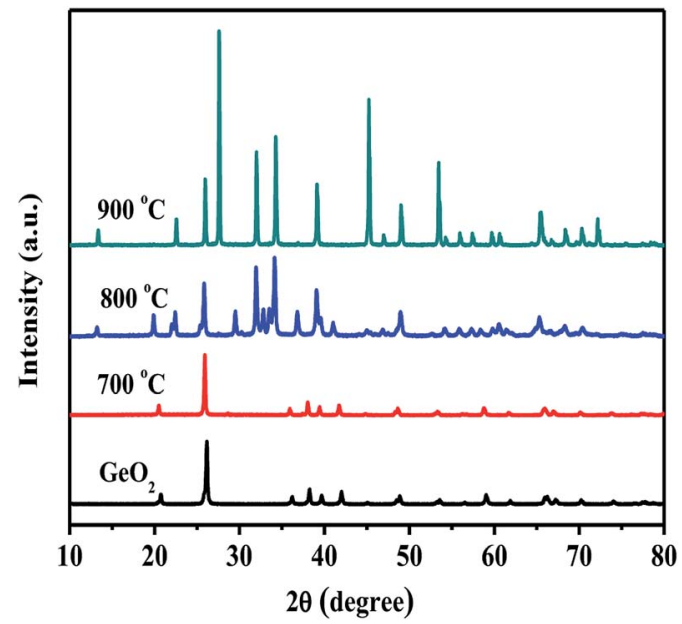

Fig. 1 XRD patterns of commercial $\mathrm{GeO}_{2}$ and $\mathrm{GeO}_{2}$ calcined in $\mathrm{NH}_{3}$ flow at different temperatures for $2 \mathrm{~h}$.

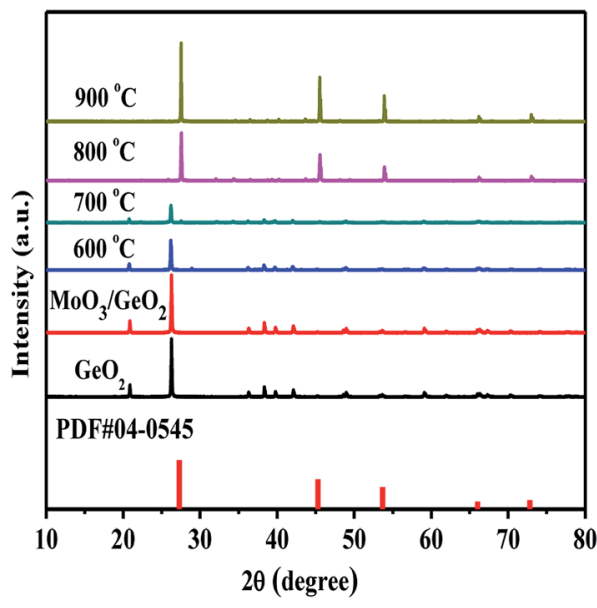

Fig. 2 XRD patterns of commercial $\mathrm{GeO}_{2}$ and samples of $5.0 \mathrm{wt} \%$ $\mathrm{MoO}_{3} / \mathrm{GeO}_{2}$ calcined in $\mathrm{NH}_{3}$ flow at different temperatures for $2 \mathrm{~h}$.

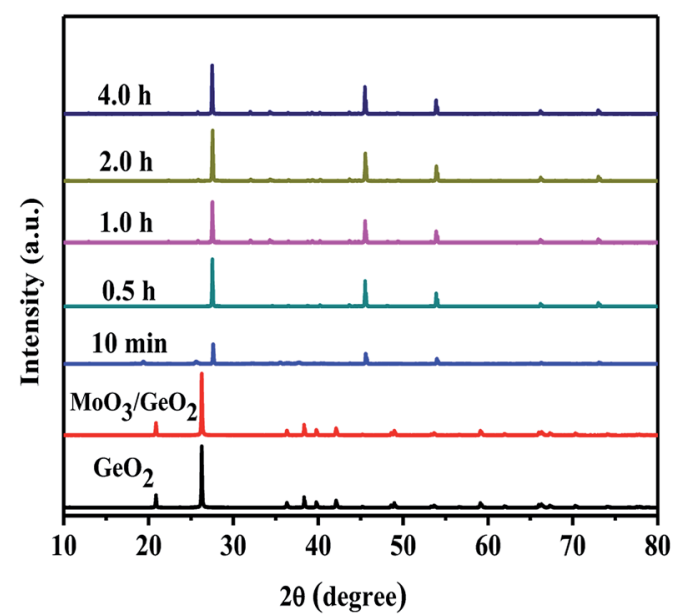

Fig. 3 XRD patterns of commercial $\mathrm{GeO}_{2}, 5.0 \mathrm{wt} \% \mathrm{MoO}_{3} / \mathrm{GeO}_{2}$ and $5.0 \mathrm{wt} \% \mathrm{MoO}_{3} / \mathrm{GeO}_{2}$ calcined in $\mathrm{NH}_{3}$ flow at $800{ }^{\circ} \mathrm{C}$ for different time.

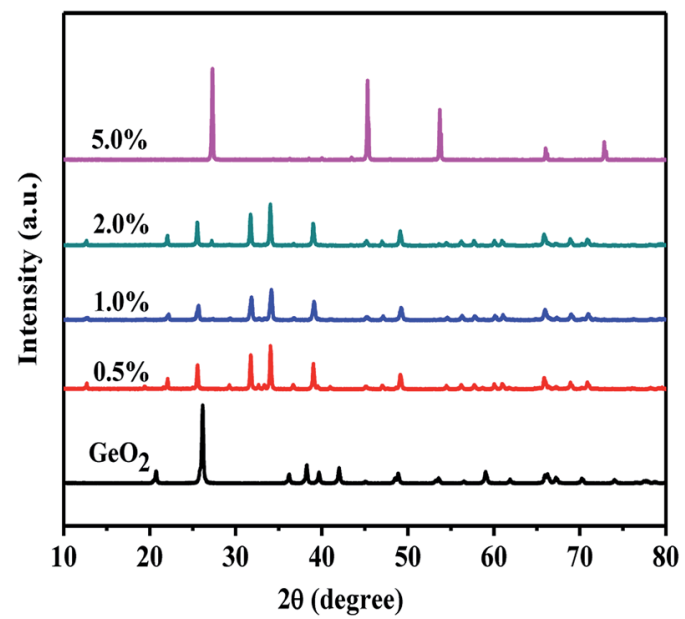

Fig. 4 XRD patterns of $\mathrm{GeO}_{2}$ and $\mathrm{MoO}_{3} / \mathrm{GeO}_{2}$ with different $\mathrm{MoO}_{3}$ loading mass ratio calcined in $\mathrm{NH}_{3}$ flow at $800{ }^{\circ} \mathrm{C}$ for $0.5 \mathrm{~h}$. 
$\left.{ }^{\circ} \mathrm{C}\right)$ without any catalyst, we inferred the process $\mathrm{Ge}$ generation is that first the $\mathrm{GeO}_{2}$ transfers into $\mathrm{Ge}_{3} \mathrm{~N}_{4}$, and then the $\mathrm{Ge}_{3} \mathrm{~N}_{4}$ decomposes into Ge with the Mo base catalyst. This ultra fast method of Ge generation using Mo based catalyst has major advantages of low cost and high efficiency.

\subsection{Determination of the catalyst of Ge generation}

It is well known the molybdenum oxide will change into molybdenum nitride in $\mathrm{NH}_{3}$ atmosphere at high temperature. So, it is necessary to judge which Mo species play the catalytic role in the Ge generation. Fig. 5 shows XRD patterns of $\mathrm{MoO}_{3}$ calcined in the $\mathrm{NH}_{3}$ flow at different temperatures. At $600{ }^{\circ} \mathrm{C}$, some $\mathrm{MoO}_{3}$ (PDF \# 35-0609) is reduced into $\mathrm{MoO}_{2}$ (PDF \# 320671). When the temperatures reach at and above $700{ }^{\circ} \mathrm{C}$, all $\mathrm{MoO}_{3}$ is converted to $\mathrm{Mo}_{2} \mathrm{~N}$ (PDF \# 25-1366). In Fig. 2, Ge is generated at $800{ }^{\circ} \mathrm{C}$ from $\mathrm{MoO}_{3} / \mathrm{GeO}_{2}$. At this moment $\left(800{ }^{\circ} \mathrm{C}\right)$, the $\mathrm{MoO}_{3}$ had been reduced into $\mathrm{Mo}_{2} \mathrm{~N}$ (Fig. 5, $800{ }^{\circ} \mathrm{C}$ ), and the $\mathrm{GeO}_{2}$ had been reduced into $\mathrm{Ge}_{3} \mathrm{~N}_{4}$ (Fig. $1,800^{\circ} \mathrm{C}$ ). These results indicate that the $\mathrm{Mo}_{2} \mathrm{~N}$ generated by $\mathrm{MoO}_{3}$ acts as a catalyst and improves the decomposition of the $\mathrm{Ge}_{3} \mathrm{~N}_{4}$ into Ge.

In order further determine the origination $\left(\mathrm{Mo}_{2} \mathrm{~N}\right.$ or $\left.\mathrm{MoO}_{3}\right)$ of the catalysis role in Ge generation, the calcination experiments in nitrogen flow using $\mathrm{GeO}_{2}$ and $\mathrm{Ge}_{3} \mathrm{~N}_{4}$ as raw materials have been designed. Fig. 6 shows the XRD patterns of $\mathrm{Mo}_{2} \mathrm{~N}$ / $\mathrm{GeO}_{2}, \mathrm{MoO}_{3} / \mathrm{GeO}_{2}, \mathrm{Mo}_{2} \mathrm{~N} / \mathrm{Ge}_{3} \mathrm{~N}_{4}$ and $\mathrm{MoO}_{3} / \mathrm{Ge}_{3} \mathrm{~N}_{4}$ calcined in $\mathrm{N}_{2}$ atmosphere at $800{ }^{\circ} \mathrm{C}$ for $2 \mathrm{~h}$. It can be seen that there are all a small amount of Ge generated by the addition of $\mathrm{Mo}_{2} \mathrm{~N}$ whether the raw material is $\mathrm{GeO}_{2}$ or $\mathrm{Ge}_{3} \mathrm{~N}_{4}$. However, by the addition of $\mathrm{MoO}_{3}$, there is no Ge generation for both $\mathrm{MoO}_{3}$ / $\mathrm{GeO}_{2}$ and $\mathrm{MoO}_{3} / \mathrm{Ge}_{3} \mathrm{~N}_{4}$. These again demonstrate that $\mathrm{Mo}_{2} \mathrm{~N}$ plays the catalysis role in Ge generation, whereas $\mathrm{MoO}_{3}$ is not the catalyst.

\subsection{Comparison with the industrial preparation method of Ge in $\mathrm{H}_{2}$ flow}

In order to compare our preparation method with industrial method, $\mathrm{GeO}_{2}$ is reduced into Ge in hydrogen atmosphere has been carried out. Fig. 7 shows the XRD patterns of $\mathrm{GeO}_{2}$ calcined in hydrogen flow at different temperatures for 4 hours. At or over $500{ }^{\circ} \mathrm{C}$, Ge is generated in $\mathrm{H}_{2}$ flow, and $650{ }^{\circ} \mathrm{C}$ is

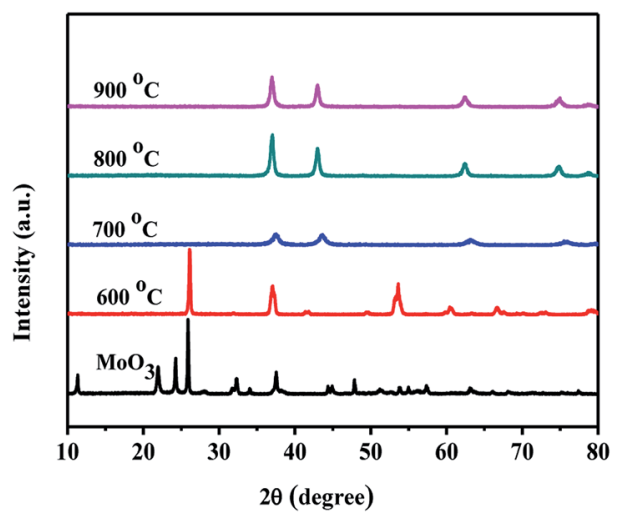

Fig. 5 XRD patterns of $\mathrm{MoO}_{3}$ and $\mathrm{MoO}_{3}$ calcined in $\mathrm{NH}_{3}$ flow at different temperatures for $2 \mathrm{~h}$.

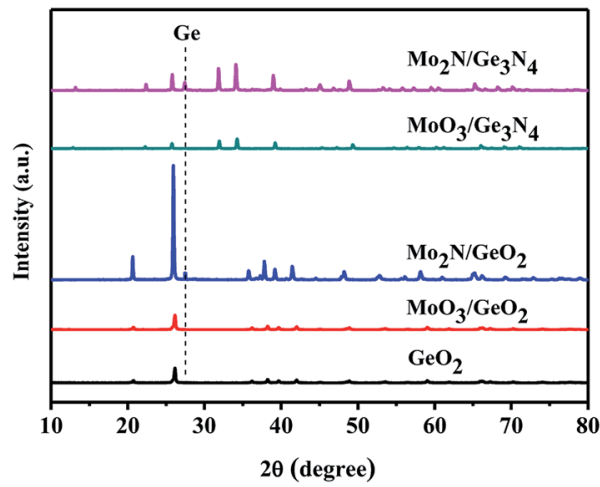

Fig. 6 XRD patterns of $\mathrm{GeO}_{2}, 5.0 \% \mathrm{Mo}_{2} \mathrm{~N} / \mathrm{GeO}_{2}, 5.0 \% \mathrm{MoO} / \mathrm{GeO}_{2}$, $5.0 \% \mathrm{Mo}_{2} \mathrm{~N} / \mathrm{Ge}_{3} \mathrm{~N}_{4}$ and $5.0 \% \mathrm{MoO}_{3} / \mathrm{Ge}_{3} \mathrm{~N}_{4}$ calcined in $\mathrm{N}_{2}$ atmosphere at $800{ }^{\circ} \mathrm{C}$ for $2 \mathrm{~h}$

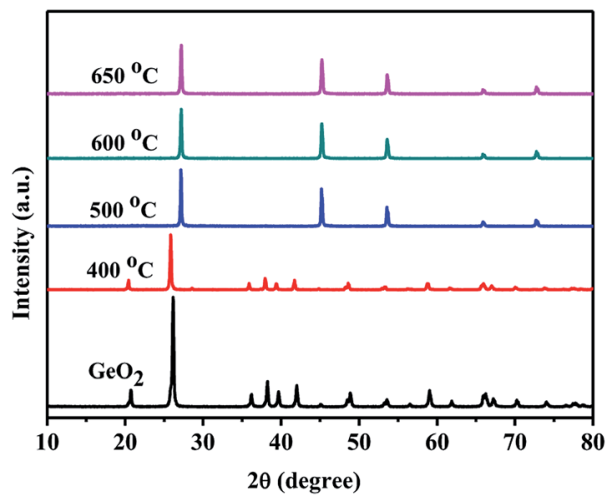

Fig. 7 XRD patterns of $\mathrm{GeO}_{2}$ calcined in hydrogen atmosphere at different temperatures for $4 \mathrm{~h}$.

chosen generally in the industry. Fig. 8 shows the XRD pattern of $\mathrm{GeO}_{2}$ calcined in hydrogen flow at $500{ }^{\circ} \mathrm{C}$ for different time. Ge can be produced in the $\mathrm{H}_{2}$ flow in 2 hours. So, compared with the industrial method in the $\mathrm{H}_{2}$ flow, our preparation method in the $\mathrm{NH}_{3}$ flow with $\mathrm{Mo}_{2} \mathrm{~N}$ catalyst has the advantages of ultra short reaction time (10 $\mathrm{min} v s .2 \mathrm{~h}$ ) and more safety $\left(\mathrm{NH}_{3}\right.$ vs. $\left.\mathrm{H}_{2}\right)$, though the reaction temperature is higher $\left(800{ }^{\circ} \mathrm{C}\right.$

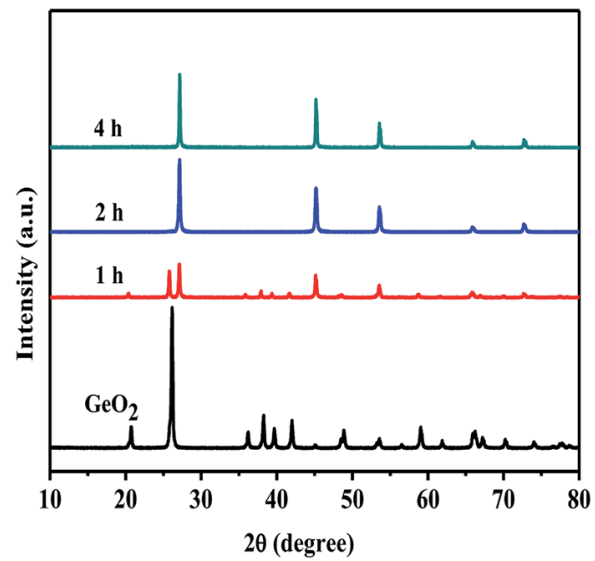

Fig. 8 XRD patterns of $\mathrm{GeO}_{2}$ calcined in $\mathrm{H}_{2}$ flow at $500^{\circ} \mathrm{C}$ for different time. 
vs. $650{ }^{\circ} \mathrm{C}$ ). We also performed the experiment which the $\mathrm{GeO}_{2}$ was calcined in $\mathrm{H}_{2}$ flow at $800{ }^{\circ} \mathrm{C}$ for the further contrast. The Fig. 9 shows the XRD pattern of $\mathrm{GeO}_{2}$ calcined in hydrogen flow at $800{ }^{\circ} \mathrm{C}$ for different time. The $\mathrm{GeO}_{2}$ was converted into Ge in 10 min under the hydrogen atmosphere at $800{ }^{\circ} \mathrm{C}$. It is similar to that of in the $\mathrm{NH}_{3}$ flow reduction. However, calcining $\mathrm{GeO}_{2}$ in an ammonia atmosphere means more secure.

\subsection{The physical properties of prepared Ge}

Fig. 10 shows the morphologies of the raw material $\mathrm{GeO}_{2}$ and the prepared $\mathrm{Ge}$ in $\mathrm{NH}_{3}$ flow with different magnifications. The $\mathrm{GeO}_{2}$ particles (Fig. 10a-c) are uniform and show sharp angular shapes. The prepared $\mathrm{Ge}$ in $\mathrm{NH}_{3}$ flow (Fig. 10d-f) shows a smooth surface and some agglomeration, indicating the structure changes from $\mathrm{GeO}_{2}$ to Ge. The size of Ge is between 5 $\mu \mathrm{m}$ and $10 \mu \mathrm{m}$. Fig. 11 shows the HRTEM of prepared Ge in $\mathrm{NH}_{3}$ flow, the lattice fringes of Ge with interplanar distances of $0.237 \mathrm{~nm}$ is indexed to the (111) planes of Ge.

In order to further explore the morphology changes in the formation process of Ge, SEM as shown in Fig. 12 has been carried out for the samples prepared from $\mathrm{MoO}_{3} / \mathrm{GeO}_{2}$ for different times and with different $\mathrm{MoO}_{3}$ mass ratios. Compared the Fig. 12b with Fig. 12a, it is found the rod-shaped material

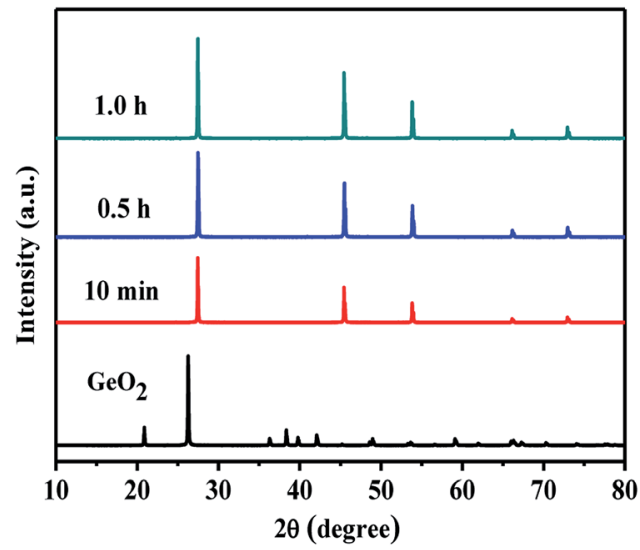

Fig. 9 XRD patterns of $\mathrm{GeO}_{2}$ calcined in $\mathrm{H}_{2}$ flow at $800^{\circ} \mathrm{C}$ for different time.
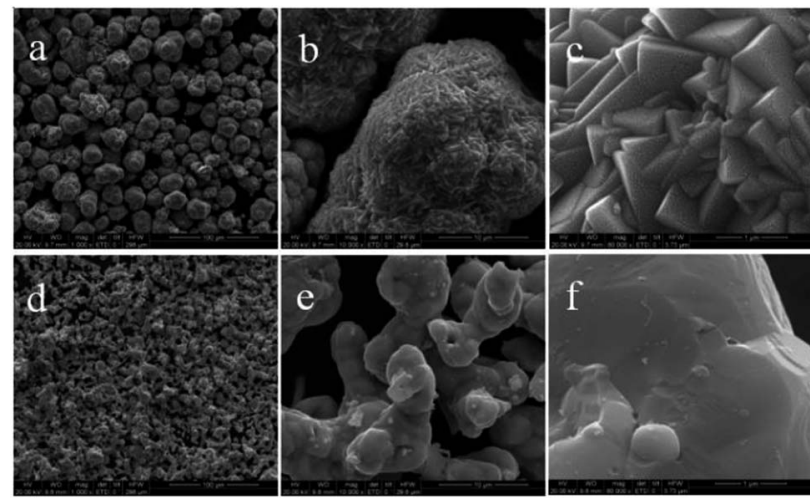

Fig. 10 SEM images of the raw material of $\mathrm{GeO}_{2}(\mathrm{a}-\mathrm{c})$ and the $\mathrm{Ge}(\mathrm{d}-\mathrm{f})$ prepared from $5 \% \mathrm{MoO}_{3} / \mathrm{GeO}_{2}$ in $\mathrm{NH}_{3}$ flow at $800{ }^{\circ} \mathrm{C}$ for $2 \mathrm{~h}$.

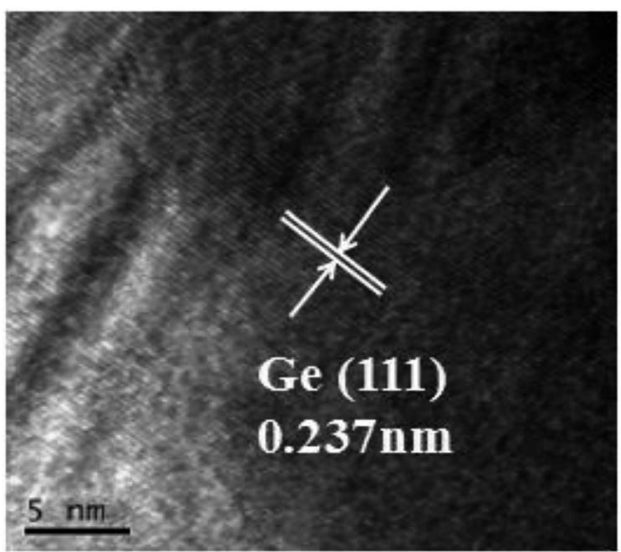

Fig. 11 HRTEM of Ge prepared in the $\mathrm{NH}_{3}$ flow from $\mathrm{GeO}_{2}$ mixed with $5.0 \% \mathrm{MoO}_{3}$ at $800{ }^{\circ} \mathrm{C}$ for $2 \mathrm{~h}$.

(Fig. 12a) decreases and the large smooth-surfaced Ge (Fig. 12b) increases with the reaction time prolonging. Associate with XRD patterns in Fig. 4, the rod-shaped material can be inferred as $\mathrm{Ge}_{3} \mathrm{~N}_{4}$. Compared the Fig. $12 \mathrm{c}$ with Fig. $12 \mathrm{~b}$, it can be seen that there is hardly any $\mathrm{Ge}_{3} \mathrm{~N}_{4}$ particles in the Fig. 12c, indicating that almost all $\mathrm{Ge}_{3} \mathrm{~N}_{4}$ transforms into Ge with the increase of $\mathrm{MoO}_{3}$. Here, the $\mathrm{MoO}_{3}$ had been converted into $\mathrm{Mo}_{2} \mathrm{~N}$ due to in the $\mathrm{NH}_{3}$ flow at $800{ }^{\circ} \mathrm{C}$ (Fig. 5, $800{ }^{\circ} \mathrm{C}$ ). Fig. 12 again demonstrates the process of $\mathrm{Ge}$ generation goes through two stages. Firstly, $\mathrm{GeO}_{2}$ is reduced to $\mathrm{Ge}_{3} \mathrm{~N}_{4}$, and then $\mathrm{Ge}_{3} \mathrm{~N}_{4}$ decomposed into Ge by the catalysis of $\mathrm{Mo}_{2} \mathrm{~N}$.

Fig. 13 shows the UV-vis diffuse reflectance spectra of $\mathrm{MoO}_{3} /$ $\mathrm{GeO}_{2}$ calcined in the $\mathrm{NH}_{3}$ flow with different mass ratios of $\mathrm{MoO}_{3}$. The raw material of $\mathrm{GeO}_{2}$ show a strong light absorption at ultraviolet region with the absorption edge of $218 \mathrm{~nm}$, which means it is a large gap semiconductor. With the amount of $\mathrm{MoO}_{3}$ increasing from 0 to $5.0 \%$, the light absorption region gradually extends from ultraviolet region to visible region and the absorption strength gradually increases. The Ge prepared from $5.0 \% \mathrm{MoO}_{3} / \mathrm{GeO}_{2}$ shows the most strongest light absorption in the range from $200 \mathrm{~nm}$ to $800 \mathrm{~nm}$. The light absorption curve of the Ge prepared in $\mathrm{NH}_{3}$ flow is same as that prepared in $\mathrm{H}_{2}$ flow except the absorption strength. The difference of absorption strength can be attributed to the small amount of $\mathrm{Mo}_{2} \mathrm{~N}$ catalyst.
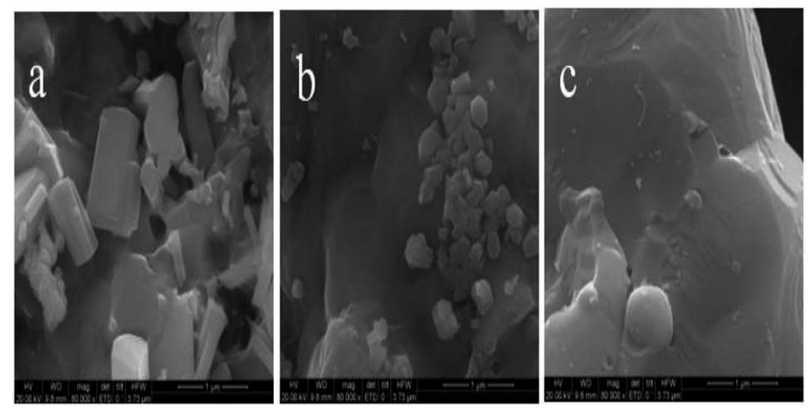

Fig. 12 SEM images of samples prepared in the $\mathrm{NH}_{3}$ flow from $2.0 \%$ $\mathrm{MoO}_{3} / \mathrm{GeO}_{2}$ at $800{ }^{\circ} \mathrm{C}$ for $0.5 \mathrm{~h}$ (a), $2.0 \% \mathrm{MoO}_{3} / \mathrm{GeO}_{2}$ at $800{ }^{\circ} \mathrm{C}$ for $2 \mathrm{~h}$ (b) $5 \% \mathrm{MoO}_{3} / \mathrm{GeO}_{2}$ at $800{ }^{\circ} \mathrm{C}$ for $2 \mathrm{~h}$ (c). 


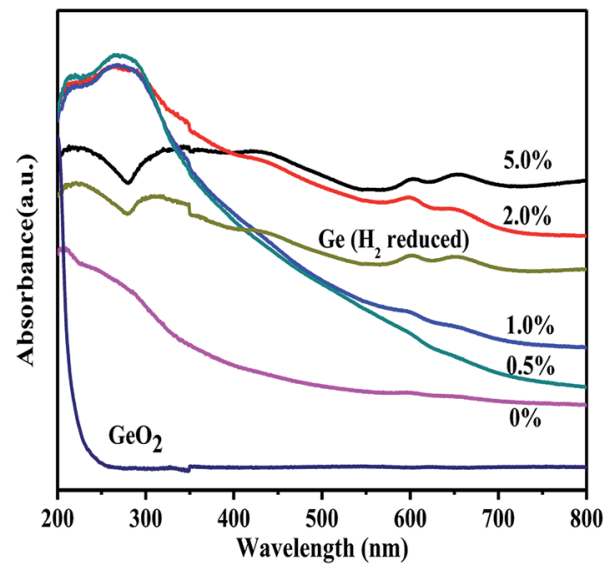

Fig. 13 The UV-visible diffuse reflectance spectra of $\mathrm{MoO}_{3} / \mathrm{GeO}_{2}$ with different mass ratios of $\mathrm{MoO}_{3}$ calcined in $\mathrm{NH}_{3}$ flow at $800{ }^{\circ} \mathrm{C}$ for $2 \mathrm{~h}$. The spectra of $\mathrm{GeO}_{2}$ and $\mathrm{Ge}$ prepared in the $\mathrm{H}_{2}$ flow at $650{ }^{\circ} \mathrm{C}$ for $4 \mathrm{~h}$ are presented for comparison.

\section{Conclusions}

A fast, low cost and safe method for the Ge synthesis has been reported by the $\mathrm{NH}_{3}$ reduction of $\mathrm{GeO}_{2}$ using a $\mathrm{Mo}_{2} \mathrm{~N}$ catalyst. When $\mathrm{GeO}_{2}$ and $5.0 \% \mathrm{MoO}_{3}$ is mixed and nitrided in $\mathrm{NH}_{3}$ flow at $800{ }^{\circ} \mathrm{C}$, the $\mathrm{Ge}$ is formed in $10 \mathrm{~min}$. The prepared Ge shows micron scale particles size and good light absorption both in the ultraviolet and visible region. The reaction mechanism of Ge generation carries out a two-stage process. $\mathrm{GeO}_{2}$ is converted into $\mathrm{Ge}_{3} \mathrm{~N}_{4}$ firstly, and then $\mathrm{Ge}_{3} \mathrm{~N}_{4}$ is decomposed into Ge with the $\mathrm{Mo}_{2} \mathrm{~N}$ catalyst. $\mathrm{Mo}_{2} \mathrm{~N}$ instead of $\mathrm{MoO}_{3}$ is demonstrated the catalyst for the Ge generation by two proofs. One is that $\mathrm{MoO}_{3}$ is converted into $\mathrm{Mo}_{2} \mathrm{~N}$ at $800{ }^{\circ} \mathrm{C}$ in the $\mathrm{NH}_{3}$ flow. Another is that a small part of $\mathrm{Ge}$ is produced from both the mixed $\mathrm{Mo}_{2} \mathrm{~N} / \mathrm{GeO}_{2}$ and the $\mathrm{Mo}_{2} \mathrm{~N} / \mathrm{Ge}_{3} \mathrm{~N}_{4}$ calcined in $\mathrm{N}_{2}$ flow, whereas there is no Ge generated from both $\mathrm{MoO}_{3} / \mathrm{GeO}_{2}$ and the $\mathrm{MoO}_{3} / \mathrm{Ge}_{3} \mathrm{~N}_{4}$. Finally, the method for Ge preparation in $\mathrm{NH}_{3}$ flow has been compared with the industrial method in $\mathrm{H}_{2}$ flow. Our presented method has the advantages of fast and safety and has great potential for industrialization. The proposed $\mathrm{Mo}_{2} \mathrm{~N}$ boosting the $\mathrm{Ge}_{3} \mathrm{~N}_{4}$ decomposition has guiding significance to other nitride decomposition system.

\section{Conflicts of interest}

There are no conflicts to declare.

\section{Acknowledgements}

This work is funded by the Natural Science Foundation of Ningxia Province of China (NZ17038), National First-rate Discipline Construction Project of Ningxia (Chemical Engineering and Technology NXYLXK2017A04), Major Innovation Projects for Building First-class Universities in China's Western Region (ZKZD2017003) and the National Natural Science Foundation of China (NSFC, 21263018).

\section{Notes and references}

1 C. B. Murray, D. J. Norris and M. G. Bawendi, J. Am. Chem. Soc., 1993, 115, 8706-8715.

2 Y. Wang and N. Herron, J. Phys. Chem., 1991, 95, 525-532.

3 L. Zhang and M. Jaroniec, Appl. Surf. Sci., 2017, 430, 2-17.

4 I. D. Samuel and G. A. Turnbull, Chem. Rev., 2007, 107, 12721295.

5 H. A. Qayyum, M. F. Al-Kuhaili, S. M. A. Durrani, T. Hussain and S. H. A. Ahmad, J. Alloys Compd., 2018, 747, 374-384.

6 Q. Yin and C. L. Hill, Joule, 2017, 1, 645-646.

7 P. Reiss, M. Carrière, C. Lincheneau, L. Vaure and S. Tamang, Chem. Rev., 2016, 116, 10731-10819.

8 A. M. Derfus, W. Chan and S. N. Bhatia, Nano Lett., 2004, 4, 11-18.

9 L. Ye, K. T. Yong, L. Liu, I. Roy, R. Hu, J. Zhu, H. Cai, W. C. Law, J. Liu, K. Wang, J. Liu, Y. Liu, Y. Hu, X. Zhang, M. T. Swihart and P. N. Prasad, Nat. Nanotechnol., 2012, 7, 453-458.

10 S. Hayashi, M. Ito and H. Kanamori, Solid State Commun., 1982, 44, 75-79.

11 J. Tauc, R. Grigorovici and A. Vancu, Phys. Status Solidi, 1966, 15, 627-637.

12 D. Carolan, Prog. Mater. Sci., 2017, 90, 128-158.

13 Z. L. Hu, S. Zhang, C. J. Zhang and G. L. Cui, Coord. Chem. Rev., 2016, 326, 34-85.

14 L. Zhang, B. G. Zhang, B. C. Pan and C. W. Wang, Appl. Surf. Sci., 2017, 422, 247-256.

15 S. V. Grayli, A. Ferrone, L. Maiolo, A. De Iacovo, A. Pecora, L. Colace, G. W. Leach and B. Bahreyni, Sens. Actuators, A, 2017, 263, 341-348.

16 W. S. Chen, B. C. Chang and K. L. Chiu, J. Environ. Chem. Eng., 2017, 5, 5215-5221.

17 J. P. Wright, L. J. Harkness-Brennan, A. J. Boston, D. S. Judson, M. Labiche, P. J. Nolan, R. D. Page, F. Pearce, D. C. Radford, J. Simpson and C. Unsworth, Nucl. Instrum. Methods Phys. Res., Sect. A, 2018, 892, 84-92.

18 Y. Matsuura, Curr. Appl. Phy., 2017, 17, 1465-1468.

19 J. Biedrzycki, K. Tarnowski and W. Urbańczyk, Opto-Electron. Rev., 2018, 26, 57-62.

20 D. D. Liu, H. S. Liu, C. H. Jiang, J. Leng, Y. M. Zhang, Z. H. Zhao, K. W. Zhuang, Y. G. Jiang and Y. Q. Ji, Thin Solid Films, 2015, 592, 292-295.

21 Ö. M. Dag, A. Kuperman and G. A. Ozin, Adv. Mater., 1994, 6, 147-150.

22 C. R. Stoldt, M. A. Haag and B. A. Larsen, Appl. Phys. Lett., 2008, 93, 43125.

23 R. Gresback, Z. Holman and U. Kortshagen, Appl. Phys. Lett., 2007, 91, 335.

24 Z. C. Holman and U. R. Kortshagen, Langmuir, 2009, 25, 11883-11889.

25 Z. C. Holman, C. Y. Liu and U. R. Kortshagen, Nano Lett., 2010, 10, 2661-2666.

26 S. Hayashi, M. Fujii and K. Yamamoto, Jpn. J. Appl. Phys., 1989, 28, L1464-L1466.

27 Y. Maeda, N. Tsukamoto, Y. Yazawa, Y. Kanemitsu and Y. Masumoto, Appl. Phys. Lett., 1991, 59, 3168-3170. 
28 T. I. Kamins, D. A. A. Ohlberg, R. S. Williams, W. Zhang and S. Y. Chou, Appl. Phys. Lett., 1999, 74, 1773-1775.

29 G. Kartopu, A. V. Sapelkin, V. A. Karavanskii and R. Turan, J. Appl. Phys., 2008, 103, 113518.

30 S. Ngiam, K. F. Jensen and K. D. Kolenbrander, J. Appl. Phys., 1994, 76, 8201-8203.

31 D. Carolan and H. Doyle, J. Mater. Chem. C, 2014, 2, 35623568.

32 D. Carolan and H. Doyle, J. Nanomater., 2015, 16, 1-9.

33 N. Shirahata, J. Solid State Chem., 2014, 214, 74-78.

34 E. Muthuswamy, A. S. Iskandar, M. M. Amador and S. M. Kauzlarich, Chem. Mater., 2013, 25, 1416-1422.

35 I. I. Dimitri, J. F. Bondi and R. E. Schaak, Chem. Mater., 2010, 22, 6103-6108.

36 D. J. Xue, J. J. Wang, Y. Q. Wang, X. Sen, Y. G. Guo and L. J. Wan, Adv. Mater., 2011, 23, 3704-3707.

37 N. K. Mahenderkar, Y. C. Liu, J. A. Koza and J. A. Switzer, ACS Nano, 2014, 8, 9524-9530.
38 A. Lahiri, S. Z. E. Abedin and F. Endres, J. Phys. Chem. C, 2012, 116, 17739-17745.

39 C. Y. Cummings, P. N. Bartlett, D. Pugh, G. Reid, W. Levason, M. M. Hasan, A. L. Hector, J. Spencer, D. C. Snith and S. Marks, ChemElectroChem, 2016, 3, 726-733.

40 A. Lahiri, A. Willert, S. Z. E. Abedin and F. Endres, Electrochim. Acta, 2014, 121, 154-158.

41 A. Lahiri and F. Endres, J. Electrochem. Soc., 2017, 164, D597D612.

42 Q. Feng, W. Zhao and S. Wen, J. Alloys Compd., 2018, 744, 301-309.

43 A. Sánchez and M. Martín, J. Cleaner Prod., 2018, 178, 325342.

44 M. F. Ezzat and I. Dincer, Appl. Energy, 2018, 219, 226-239.

45 K. Sakuragi, K. Igarashi and M. Samejima, Polym. Degrad. Stab., 2018, 148, 19-25. 